\title{
Community-Based Accompaniment for Adolescents Transitioning to Adult HIV Care in Urban Peru:
}

\section{a Pilot Study}

Valentina Vargas, ${ }^{1 *}$ Milagros Wong, ${ }^{2 *}$, Carly A. Rodriguez, ${ }^{3}$ Hugo Sanchez, ${ }^{4}$ Jerome Galea, ${ }^{3,5,6}$ Alicia Ramos, ${ }^{2}$ Liz Senador, ${ }^{2}$ Lenka Kolevic, ${ }^{7,8}$ Eduardo Matos, ${ }^{8,9}$ Eduardo Sanchez, ${ }^{8,10}$ Renato A. Errea, ${ }^{2,3}$ Karen Ramos, ${ }^{2}$ Catherine Beckhorn, ${ }^{2}$ Andrew Lindeborg, ${ }^{3}$ Carlos Benites,${ }^{8}$ Leonid Lecca, ${ }^{2,3}$ Sonya Shin, ${ }^{11}$ Molly F. Franke $\mathrm{s}^{3 \S}$

${ }^{1}$ Department of Global Health and Population, Harvard T.H. Chan School of Public Health, Boston, MA, USA

${ }^{2}$ Socios En Salud Sucursal Peru, Lima, Peru

${ }^{3}$ Department of Global Health and Social Medicine, Harvard Medical School, Boston, MA, USA

${ }^{4}$ Epicentro, Lima, Peru

${ }^{5}$ School of Social Work, University of South Florida, Florida, USA

${ }^{6}$ College of Public Health, University of South Florida, USA

${ }^{7}$ Servicio de Infectología, Instituto Nacional del Salud del Niño, Lima, Peru

${ }^{8}$ Programa de ITS, VIH/SIDA y hepatitis, Ministerio de Salud, Lima, Peru

${ }^{9}$ Servicio de Infectología, Hospital Nacional Arzobispo Loayza, Lima, Peru

${ }^{10}$ Servicio de Enfermedades Infecciosas y Tropicales, Hospital Nacional Hipólito Unanue, Lima, Peru

${ }^{11}$ Division of Global Health Equity, Brigham and Women's Hospital, Boston, MA, USA

$\S$ Corresponding author:

Molly F. Franke

641 Huntington Avenue

Boston, MA 02118, United States of America

$+1(617) 432-5224$ 
molly_franke@hms.harvard.edu

*These authors have contributed equally to the work.

E-mail addresses of authors:

VV: vvargas@hsph.harvard.edu

MW: mwong_ses@pih.org

CR: carly_rodriguez@hms.harvard.edu

HS: hsanchez@epicentro.org.pe

JG: jeromegalea@usf.edu

AR: aramos_ses@pih.org

LA: 1senador_ses@pih.org

LK: 1kolevic@insn.gob.pe

EM: ematos88@hotmail.com

ES: esanchez2018@hotmail.com

RE: rerrea_ses@pih.org

CB: catherine.beckhorn@duke.edu

AL: andrew_lindeborg@hms.harvard.edu

CB: cbenites@minsa.gob.pe

LL:1lecca_ses@pih.org

SS: sshin@bwh.harvard.edu

Keywords: adolescents, social support, adherence, differentiated care, HIV care continuum, key and vulnerable populations

Abstract: $345 / 350$

Main text: $3580 / 3500$ 
medRxiv preprint doi: https://doi.org/10.1101/2021.08.25.21261815; this version posted August 26, 2021. The copyright holder for this preprint (which was not certified by peer review) is the author/funder, who has granted medRxiv a license to display the preprint in perpetuity.

All rights reserved. No reuse allowed without permission.

1

2

3

4

5

6

7

8

9

\section{Abstract}

Introduction: Adolescents living with HIV (ALWH) face an elevated risk of poor health outcomes when transitioning into adult-oriented care; however, evidence-based interventions to support ALWH during this high-risk period are lacking, especially in Latin America. We conducted a pilot study of a community-based intervention designed to improve outcomes among ALWH transitioning to adult HIV care in Lima, Peru.

Methods: From October 2019 to January 2020, we enrolled adolescents transitioning to adult HIV care, either due to a recent diagnosis or having aged out of their pediatric clinic. ALWH previously lost from care during the transition process were also invited to participate. The nine-month intervention consisted of (1) logistical, adherence and social support delivered by entry-level health workers who accompanied adolescents during their transition to adult HIV care and (2) group sessions to improve health-related knowledge, skills and social support. We assessed intervention feasibility and effectiveness in improving medication adherence, psycho-social outcomes, and transition readiness after 6, 9, and 12 months.

Results: We enrolled 30 ALWH, ages 15-21 years; 11 were recently diagnosed and 19 had been living with HIV since infancy or early childhood. Participants included ten men who have sex with men, four young pregnant women and six adolescents who were previously lost during the transition to adult HIV care. Intervention participation was high with $90 \%$ of ALWH attending at least one in-person social support session and all attending at least one live online session. No ALWH withdrew from the intervention, study, or antiretroviral therapy. In transition readiness, we observed within-person improvements related to personal health $(+1.9$ points, $\mathrm{p}<0.001)$, healthcare usage $(+2.4$ points, $\mathrm{p}<0.001)$, knowledge $(+3.3$ points, $\mathrm{p}=0.001$ ), and behavior ( +3 points, $\mathrm{p}=0.003$ ) at the end of the intervention, relative to baseline. We also observed strong evidence of improvements in medication adherence, social support, self-efficacy, and perceived stress, which were generally sustained three months after intervention cessation. 
medRxiv preprint doi: https://doi.org/10.1101/2021.08.25.21261815; this version posted August 26, 2021. The copyright holder for this preprint (which was not certified by peer review) is the author/funder, who has granted medRxiv a license to display the preprint in perpetuity.

All rights reserved. No reuse allowed without permission.

26 Conclusion: We identified a community-based intervention that is feasible and potentially effective for

27 bridging the transition to adult HIV care among a diverse group of ALWH in Peru. A larger-scale

28 effectiveness evaluation, including biological endpoints, is warranted.

29 
medRxiv preprint doi: https://doi.org/10.1101/2021.08.25.21261815; this version posted August 26, 2021. The copyright holder for this preprint (which was not certified by peer review) is the author/funder, who has granted medRxiv a license to display the preprint in perpetuity.

All rights reserved. No reuse allowed without permission.

\section{Introduction}

Expanded access to antiretroviral therapy (ART) has led to major improvements in the survival of children who acquire HIV early in life. This means that providers and programs are faced with the challenge of caring for a group of patients living with HIV that is also dealing with the many developmental, emotional and behavioral issues of adolescence. These include the desire for peer acceptance, vulnerability to mental health and substance use disorders, and the potential consequences of early sexual debut (e.g., pregnancy, HIV transmission, other sexually-transmitted infections) [1-6]. An increased risk of early life adversity and trauma among adolescents living with HIV (ALWH) may make them especially susceptible to mental health morbidity $[7,8]$. And, ALWH may lack the life skills, coping strategies and support needed to effectively manage common HIV-related challenges, such as diagnosis disclosure, HIV-related stigma and social isolation, neurocognitive delays, and navigating romantic relationships [1-3,8-11]. In spite of their unique needs, ALWH have rarely been targeted for intervention studies to improve health outcomes [1214]. The absence of tailored interventions for adolescents may in part explain their disproportionately high rates of attrition to care relative to other age groups [15].

The transition from pediatric to adult care is an exceptionally precarious time in adolescent HIV care, marked by reduced clinic attendance, retention in care, HIV viral load suppression and CD4 cell counts $[16,17]$. This transition, which often occurs in late adolescence, can be accompanied by logistical and emotional challenges, as adolescents find themselves newly independent with different medical providers in an unfamiliar and often less supportive environment $[18,19]$. Although several reviews suggest good transition outcomes may be achieved with individualized transition plans that address the multifaceted needs of adolescence [8,19-22], there are few rigorous studies testing promising interventions $[23,24]$ and a notable lack of evidence on which interventions might be most effective in supporting ALWH through this period. 
medRxiv preprint doi: https://doi.org/10.1101/2021.08.25.21261815; this version posted August 26, 2021. The copyright holder for this preprint (which was not certified by peer review) is the author/funder, who has granted medRxiv a license to display the preprint in perpetuity.

All rights reserved. No reuse allowed without permission.

Alongside an urgent need to identify effective transition intervention models is a growing recognition of the need for interventions that are tailored to local context and to specific subgroups. A recent review on care transition studies for ALWH identified an absence of studies from Latin America and the Caribbean, where the experiences of ALWH likely differ from those in high-income or high prevalence settings [24]. There is also a stark need for transition studies among adolescents with behaviorally-acquired HIV[8], including young men who have sex with men (MSM) and transgender women (TGW), as their transition experiences may differ from those of perinatally-infected adolescents [25]. As a first step toward addressing these research gaps, we conducted a pilot study to examine whether an intervention for ALWH, rooted in community-based support, could be a feasible approach for bridging the transition to adult HIV care among a diverse group of adolescents in an urban Latin American setting.

\section{Methods}

\section{Study setting}

In Peru, there are an estimated 87,000 people living with HIV, with the highest concentration in the capital, Lima $[26,27]$. While perinatal infection constitutes the majority of HIV infections in younger adolescents, most new infections in Peru occur among MSM and TGW, reflecting Peru's concentrated epidemic [28]. Pregnancy during adolescence is common with $17 \%$ of 20 - to 24 -year-old women giving birth before age 18 [29]. ART is available free-of-charge and is largely centralized with most patients receiving treatment through public sector hospitals.

For adolescents that acquired HIV in early childhood HIV, the transition from a pediatric to an adult HIV clinic often occurs at age 18, though it may occur as young as 15 for adolescents transitioning within the same health facility. Older, newly-diagnosed adolescents may transition directly into adult HIV care, bypassing the pediatric clinic. If an adolescent in pediatric care becomes pregnant, she immediately transitions to an adult HIV clinic, regardless of age. The existing standard of care for adolescents 
medRxiv preprint doi: https://doi.org/10.1101/2021.08.25.21261815; this version posted August 26, 2021. The copyright holder for this preprint (which was not certified by peer review) is the author/funder, who has granted medRxiv a license to display the preprint in perpetuity.

All rights reserved. No reuse allowed without permission.

80

81

82

83

\section{$84 \quad$ Participants}

85 We enrolled ALWH aged 15 to 21 years who were on or eligible for ART, enrolled in HIV care at a

transitioning to adult care includes a public health insurance referral and a series of consults with a nurse, infectious disease specialist, psychologist, and social worker prior to transition. The patient is given a report from each provider team, which the ALWH is responsible for bringing to their first adult clinic visit. participating public sector clinic, and scheduled to transition to adult HIV care, either due to a recent HIV diagnosis or because they had aged out of their pediatric clinic. ALWH who were lost from adult HIV care at the time of transition but interested in re-engaging in treatment were also eligible to participate. Adolescents were excluded if they lived outside of metropolitan Lima. Enrollment took place from October 2019 to January 2020 at three public sector hospitals (one pediatric facility, and two facilities with distinct on-site pediatric and adult clinics). Ministry of Health $(\mathrm{MoH})$ clinical collaborators consecutively referred eligible participants to study staff. A Youth Advisory Board (YAB), comprising a diverse group of young people living with HIV provided feedback on all aspects of the study. Adolescents who had previously withdrawn from care were referred by their clinicians or YAB members and contacted by study staff.

\section{Study Intervention}

The intervention was nicknamed "PASEO" (meaning 'crossing' or 'passage' in Spanish) after its core elements: peer engagement, accompaniment, support and education. In short, PASEO aimed to provide inperson accompaniment to ALWH throughout the transition process through the provision of individualized support, including adherence support, to address barriers to care and treatment (e.g., transport costs, inaccessibility of services, lack of social support) by providing medical, material, and social support delivered by compensated entry-level or lay health workers who liaise with formal health services (Figure 1).[30] 
HEALTH SYSTEM NAVIGATION AND CLINIC VISIT ACCOMPANIMENT
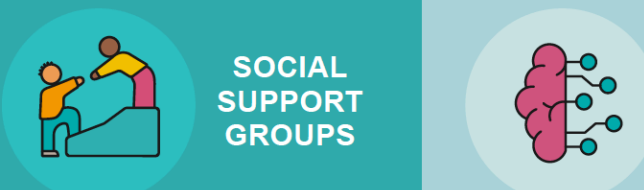

SCREENING AND

REFERRAL TO

MENTAL HEALTH SERVICES

Figure 1. Key components of the PASEO intervention

INDIVIDUALIZED

ADHERENCE

SUPPORT AND

RESOLUTION OF

ACUTE NEEDS

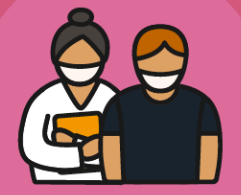

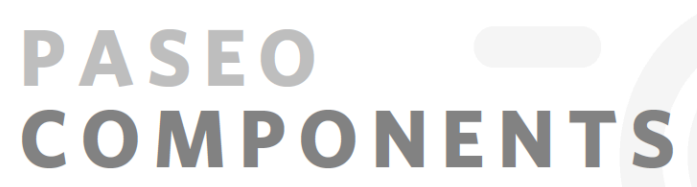

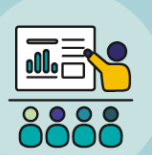

HEALTH
EDUCATIO

EDUCATION

BUILDING

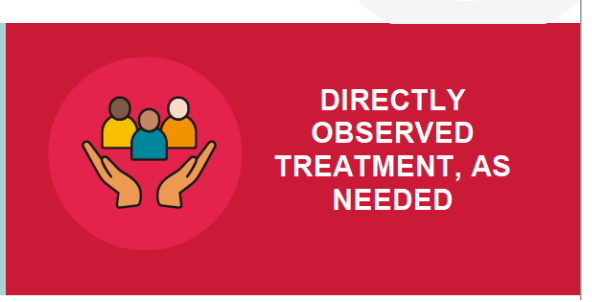

PASEO also aimed to foster health-related skills, knowledge, and psychosocial well-being needed to thrive in the adult clinic and more broadly. Intervention activities were delivered in two phases, an intensive phase and a taper phase (Figure 2). The intensive phase began just prior to transition (defined as the last date of 110 care at the pediatric clinic or, for adolescents initiating treatment directly in an adult clinic, the ART 111 initiation date) and ended after six months. A three-month taper phase, during which the intensity of study 112 activities was reduced, followed the intensive phase. Below we describe each intervention component in

113 detail (Figure 1), as well as adaptations made to accommodate stay-at-home orders invoked on March 15, 114 2020, due to the SARS-CoV-2 pandemic. Participants had received between 1.4 and 5.3 months of in115 person intervention (median: 3.1 [IQR: 2.2, 4.2]) when in-person activities were suspended and were 116 provided phone credit to enable participation in virtual programming. 


\begin{tabular}{|c|c|c|c|c|c|c|c|c|c|c|c|}
\hline \multirow{4}{*}{ Intervention activities } & \multicolumn{11}{|c|}{ Months } \\
\hline & $\mathbf{0}$ & 1 & 2 & 3 & 4 & 5 & 6 & 7 & 8 & 9 & 10-12 \\
\hline & Pre-transition & \multicolumn{9}{|c|}{ Post-transition } & Follow-up \\
\hline & \multicolumn{7}{|c|}{ Intensive Phase } & \multicolumn{3}{|c|}{ Taper phase } & No intervention \\
\hline Social worker assessment ${ }^{\mathrm{a}}$ & $\mathrm{X}$ & & & & & & & & & & \\
\hline Depression screening and referral ${ }^{\mathrm{a}}$ & $\mathrm{X}$ & & & & & & & & & & \\
\hline Health insurance navigation, clinic accompanimenta, & $\mathrm{X}$ & $\mathrm{X}$ & & & & & & & & & \\
\hline $\begin{array}{c}\text { In-person check-in with health promoter, once monthly } \\
\rightarrow \text { virtual, weekly }\end{array}$ & $\mathrm{X}$ & $\mathrm{X}$ & $\mathrm{X}$ & $X$ & $\mathrm{X}$ & $\mathrm{X}$ & $\mathrm{X}$ & $\mathrm{X}$ & & $\mathrm{X}$ & \\
\hline Clinic transportation stipend, as needed & & $\mathrm{X}$ & $\mathrm{X}$ & $\mathrm{X}$ & $\mathrm{X}$ & $\mathrm{X}$ & $\mathrm{X}$ & $\mathrm{X}$ & & & \\
\hline Establish plan for taper phase & & & & & & $X$ & $X$ & & & & \\
\hline $\begin{array}{l}\text { Social support groups, twice monthly } \\
\quad \rightarrow \text { replaced with virtual social activities }\end{array}$ & & $X$ & $X$ & $X$ & $X$ & $\mathrm{X}$ & $X$ & $X$ & $X$ & $X$ & \\
\hline $\begin{array}{l}\text { Health education and skill-building sessions, monthly } \\
\rightarrow \text { virtual, 1-3 times weekly }\end{array}$ & & $X$ & $X$ & $X$ & $X$ & $X$ & $X$ & $X$ & $X$ & $X$ & \\
\hline DOT, if indicated & & & & & & & & & & & \\
\hline $\begin{array}{l}\text { DOT daily } \\
\qquad \text { virtual }\end{array}$ & & $\mathrm{X}$ & $X$ & $X$ & $X$ & $X$ & $X$ & & & & \\
\hline $\begin{array}{r}\text { DOT twice weekly } \\
\rightarrow \text { virtual }\end{array}$ & & & & & & & & $X$ & $X$ & & \\
\hline $\begin{aligned} \text { DOT weekly } & \\
& \rightarrow \text { virtual }\end{aligned}$ & & & & & & & & & & $X$ & \\
\hline
\end{tabular}

\section{Figure 2. Overview of PASEO intervention implementation. DOT, Directly Observed Treatment}

a. Occurred more frequently, as needed

b. Accompaniment to clinic visits typically occurred through months two or three, with longer durations for those previously lost from care, experienced adverse reactions or side effects of treatment, or had concomitant health issues. Clinic visit accompaniment occurred for shorter durations if the adolescent received this support from a caregiver or family member.

c. Italicized text represents modifications made in response to the SARS-CoV-2 pandemic 
medRxiv preprint doi: https://doi.org/10.1101/2021.08.25.21261815; this version posted August 26, 2021. The copyright holder for this preprint (which was not certified by peer review) is the author/funder, who has granted medRxiv a license to display the preprint in perpetuity.

All rights reserved. No reuse allowed without permission.

Health system navigation and clinic accompaniment. To facilitate the transition to care in the adult clinic, trained health promoters (entry-level health workers with a technical degree) employed by the nongovernmental organization Socios En Salud (SES) accompanied adolescents to their first appointments; facilitated enrollment in public health insurance and completion of other administrative requisites (e.g., obtaining a foreign identification card for migrants; transferring to a different health facility); helped troubleshoot new logistical and/or social challenges (e.g., housing instability); and served as a liaison between the patient and pediatric and adult clinical providers. Clinic visit transportation was provided based on economic need, as determined by the study social worker. All but one participant had attended at least one accompanied in-person clinic visit at the time SARS-CoV-2 stay-at-home orders were invoked. The exception was an individual who was scheduled to re-initiate care in mid-March 2020. While hospital guidelines precluded in-person accompaniment for this participant, intervention staff coordinated with HIV program staff to ensure that adolescent would be seen in the clinic. Study staff coordinated private telehealth appointments for adolescents requiring clinical consultation during stay-at-home orders.

Routine check-in visits. Health promoters visited the participant's home or another mutually-agreed upon location at least monthly, to review ART adherence, identify barriers to care and adherence, remind patients of upcoming medical encounters, screen and follow-up for clinical and social problems and offer social support. The frequency of check-ins was individualized and commensurate with the level of support needed. Visits tended to occur more frequently for participants lacking family support, re-initiating ART or with a history of unstable adherence.

Directly Observed Treatment (DOT). Home-based DOT was offered to adolescents with early childhood infection identified as at risk of non-adherence (based on pediatric health provider assessment or a detectable viral load at one of two previous measurements). ALWH newly initiating ART chose whether they wished to receive DOT. Eligible ALWH who opted into DOT were assigned to a MoH community health worker (CHW) from the same neighborhood to observe ART ingestion daily, ensure treatment was 
medRxiv preprint doi: https://doi.org/10.1101/2021.08.25.21261815; this version posted August 26, 2021. The copyright holder for this preprint (which was not certified by peer review) is the author/funder, who has granted medRxiv a license to display the preprint in perpetuity.

All rights reserved. No reuse allowed without permission.

taken as prescribed and offer social support. Following invocation of stay-at-home orders, DOT was conducted virtually by SES health promotors via telephone, video or SMS, depending on participant preference. Some participants elected to participate in group video DOT, creating an additional opportunity to build social support.

Social support groups, health education sessions and skill-building workshops. Social support groups took place twice monthly (10 adolescents per group). The two-hour sessions were facilitated by a Peruvian study psychologist and one peer youth living with HIV. Based on timing of enrollment, between two and five inperson sessions were offered to each adolescent prior to stay-at-home orders. Conducting these sessions online was largely unsuccessful: many adolescents felt they lacked privacy at home to discuss personal topics [31], and others could not use video due to unstable internet. To build and sustain social connectedness, staff implemented online social activities including an HIV-related meme competition, a TikTok video competition, and a virtual talent show.

Health education sessions and skill-building workshops were conducted on topics such as HIV, substance use, sexual health, self-esteem, nutrition, and gender and sexual identity. In-person sessions took place at least once monthly (coinciding with social support group sessions), while virtual sessions took place one to three times weekly (total of 41). For virtual sessions, participants could join live, allowing interaction with the speaker and other participants via chat, or view a recording.

Mental health screening, referral and support. Participants were evaluated for depressive symptoms using the Patient Health Questionnaire-9 (PHQ-9), a tool previously validated in Spanish [32], and widely used in Peru [33]. Adolescents screening positive for mild or greater depressive symptoms (PHQ-9 $\geq 10$ ) or with suicidal ideation were evaluated by a SES' mental health program and offered Psychological First Aid [34] and referrals as needed. Participants with severe depressive symptoms (PHQ-9 $\geq 20$ ) or suicidal ideation 
medRxiv preprint doi: https://doi.org/10.1101/2021.08.25.21261815; this version posted August 26, 2021. The copyright holder for this preprint (which was not certified by peer review) is the author/funder, who has granted medRxiv a license to display the preprint in perpetuity.

All rights reserved. No reuse allowed without permission.

170

171 and delivered at nearby community mental health centers [35].

172

173 Data Collection

174 Data collection took place from October 2019 to January 2021 and included indicators of intervention 175 feasibility and effectiveness, and social, clinical, and demographic factors that could challenge transition.

176

177 Feasibility indicators aligned with selected dimensions of acceptability and demand [36]. Acceptability 178 focuses on the extent to which a program is judged as suitable or attractive. We assessed acceptability 179 through study refusal rates (i.e., the proportion of potentially eligible individuals for the study who chose 180 not to participate) and intervention retention rates (i.e., the proportion of individuals who were retained in the study). The demand domain describes the extent to which a new intervention is likely to be used. We assessed demand through intervention retention rates and group attendance for study activities. Group attendance was assessed by the proportion of individuals who attended activities, the number who attended

184 at least one session, the median number of groups attended by participants who attended at least one session, median number of participants per session, and the number of engagements (i.e., typed comments) during virtual sessions.

Preliminary evidence of effectiveness is an impact indicator examining whether a new intervention shows promise of success with the intended population. We generated preliminary evidence of effectiveness by calculating within-person changes in self-reported adherence, perceived social and instrumental support, self-efficacy and stress, and transition readiness at 6, 9, and 12-months, relative to baseline. Follow-up measurements corresponded to the end of the intensive phase, the end of the taper phase, and three months after intervention, respectively. 
medRxiv preprint doi: https://doi.org/10.1101/2021.08.25.21261815; this version posted August 26, 2021. The copyright holder for this preprint (which was not certified by peer review) is the author/funder, who has granted medRxiv a license to display the preprint in perpetuity.

All rights reserved. No reuse allowed without permission.

Baseline clinical data, including CD4 cell count and viral load, were recorded from clinical charts. Followup measurements were rarely available due to testing disruptions resulting from the SARS-CoV-2 pandemic.

Instruments. Participants self-administered surveys in Spanish on a tablet device. We assessed self-reported adherence during the prior 30-day period with three questions: "How many days did you miss at least one dose of any of your ART medications?"; "How often did you take your ART medications correctly?" (5point scale with 5 representing "always" and 1 representing "never"); "How well would you say you took your HIV medications, as directed by your doctor?" (6-point scale with 6 representing "excellent" and 1 representing "very bad"). We assessed perceived instrumental support, emotional support, perceived stress, and self-efficacy using the Spanish fixed-form version of the NIH Toolbox Emotion Battery (version 2.0) for ages 18-85. All have a 5-point ordinal scale ranging from "never" to "always", with higher scores indicating higher levels [37,38]. We evaluated transition readiness with two scales. “Am I On TRAC?” [39] consists of knowledge and behavior indices, which we adapted to the local context (see Appendix). The knowledge scale assesses the respondent's health condition and general medical self-care. The behavior scale measures the frequency with which respondents engage in individual health-related behaviors related to the developmental model of transition. We also used the Got Transition? checklist (version 2.0), which assesses personal health knowledge and use of medical services [40]. The questionnaire has a 3-point scale ranging from "not my responsibility" to "yes, I know this." For both measures, we report the summed score of responses for each subscale; higher scores indicate greater knowledge, engagement or use.

\section{Statistical Analysis}

Feasibility indicators were reported as descriptive statistics. To examine changes in outcomes during the different phases of intervention implementation, we calculated within-person change from baseline to each of the three follow-up points and tested whether this quantity differed from zero, using paired t-tests or Wilcoxon signed rank tests, as appropriate. For the NIH toolbox measurements, we report raw scores 
medRxiv preprint doi: https://doi.org/10.1101/2021.08.25.21261815; this version posted August 26, 2021. The copyright holder for this preprint (which was not certified by peer review) is the author/funder, who has granted medRxiv a license to display the preprint in perpetuity.

All rights reserved. No reuse allowed without permission.

221 instead of the t-values validated in a U.S. population. To understand whether potential effectiveness differed

222 among subgroups, we stratified analyses by early childhood versus recent diagnosis and whether the

223 adolescent had been lost from care or had a history of chronic non-adherence. Data were analyzed using

224 SAS version 9.4 (Cary, NC).

225

226 Compliance of Ethical Standards

227 The authors declare no conflicts of interest. Ethical approval was granted in Peru by the Institutional

228 Research Ethics Committees of the Instituto Nacional de Salud del Niño, Hospital Nacional Arzobispo

229 Loayza, and Hospital Nacional Hipólito Unanue. In addition, ethical approval was granted by the

230 Institutional Review Board (IRB) of the Harvard Faculty of Medicine at Harvard Medical School in the

231 USA. Written informed consent was obtained from adolescents 18 years of age and over or from guardian(s)

232 of adolescents $<18$ years. Participants $<18$ years provided informed assent. Three adolescents $<18$ years

233 without a guardian provided assent and were granted a waiver of consent.

235 Results

236 We enrolled 30 ALWH (ten per hospital), with a median age of 19 years [interquartile range (IQR): 18-20].

237 The cohort included 19 (63\%) ALWH who acquired HIV in early childhood, 13 (43\%) ALWH who

238 identified as female (including one transgender women), 10 (33\%) men who reported having sex with other

239 men, five (17\%) Venezuelan nationals, and four young pregnant women (13\%) (Table 1). Six (20\%) had

240 been lost from care at the time of enrollment (Table 1).

241

242

243

244

245 
Table 1. Baseline characteristics of adolescent participants transitioning to adult HIV care, Lima, 248 Peru $(\mathbf{N}=\mathbf{3 0})^{\mathbf{a}}$

\begin{tabular}{|c|c|c|c|}
\hline Characteristics & $\begin{array}{l}\text { All participants } \\
\qquad \mathbf{N}=\mathbf{3 0}(\%)^{\mathrm{a}}\end{array}$ & $\begin{array}{c}\text { Early childhood } \\
\text { infection } \\
\mathrm{N}=19\end{array}$ & $\begin{array}{c}\text { Recent infection } \\
\mathbf{N}=11\end{array}$ \\
\hline Age, in years, median [25th, $\left.75^{\text {th }}\right]$ & $19[18-20]$ & 19 [18-20] & $19[18-20]$ \\
\hline Female assigned at birth & $12(40)$ & $11(58)$ & $1(9)$ \\
\hline Female gender identity & $13(43)$ & $11(58)$ & $2(18)$ \\
\hline Identifies as MSM & $10(33)$ & $1(5)$ & $9(82)$ \\
\hline Pregnant & $4(13)$ & $3(16)$ & $1(9)$ \\
\hline $\begin{array}{l}\text { CD } 4 \text { count cells } / \mathrm{mm} 3 \\
\text { median }[\mathrm{IQR}]\end{array}$ & 544 [349-615] & $553[381-608]$ & $535[331-608]$ \\
\hline $\begin{array}{l}\text { Days from CD4 test to enrollment } \\
\text { median [IQR] }\end{array}$ & $130[51-272]$ & $235[127-322]$ & $55[36-63]$ \\
\hline Suppressed viral load & $10(33)$ & $9(47)$ & $1(9)$ \\
\hline $\begin{array}{l}\text { Days from viral load test to } \\
\text { enrollment median [IQR] }\end{array}$ & $71[45-161]$ & $144[54-235]$ & $55[54-52]$ \\
\hline $\begin{array}{l}\text { Lost from care at the time of } \\
\text { enrollment }\end{array}$ & $6(20)$ & $6(20)$ & $0(0)$ \\
\hline Venezuelan nationality & $5(17)$ & $1(5)$ & $4(36)$ \\
\hline At least one living parent & $19(63)$ & $8(42)$ & $11(100)$ \\
\hline At least one traumatic life event ${ }^{b}$ & $21(70)$ & $11(58)$ & $10(91)$ \\
\hline $\begin{array}{l}\text { Experienced sexual abuse (rape, } \\
\text { attempted rape, or any type of forced } \\
\text { or threatened sexual act) }\end{array}$ & $12(40)$ & $5(26)$ & $7(64)$ \\
\hline $\begin{array}{l}\text { Urban hassles index } \\
\text { median [IQR] (range 0-96) }\end{array}$ & $20[13-27]$ & $19[11-27]$ & $21[17-27]$ \\
\hline Unstable housing & $4(13)$ & $4(21)$ & $0(0)$ \\
\hline Depression (mild to severe, $\mathrm{N}=28$ ) & $16(57)$ & $10(56)$ & $6(60)$ \\
\hline
\end{tabular}

${ }^{a}$ Unless otherwise noted

${ }^{b}$ Lifetime traumatic events were measured with the Life Events Checklist for DSM-5 (LEC-5) [41,42].

${ }^{c}$ We assessed exposure to daily stressors using an adapted version of the 17-item Urban Hassles Index [42,43], a tool designed to measure stressors affecting adolescents living in urban environments.

\section{Feasibility indicators}

Of 36 adolescents referred for participation, six refused to participate (16.7\%). Four were adolescents who had previously withdrawn from HIV care and did not wish to reengage. Two opted out because of scheduling conflicts with study activities. Once enrolled, no participant withdrew from the intervention, study, or ART. Of the 30 adolescents, all but three (90\%) attended at least one in-person social support 
medRxiv preprint doi: https://doi.org/10.1101/2021.08.25.21261815; this version posted August 26, 2021. The copyright holder for this preprint (which was not certified by peer review) is the author/funder, who has granted medRxiv a license to display the preprint in perpetuity.

All rights reserved. No reuse allowed without permission.

session (median among those participating in $\geq 1$ session=2 [IQR: 2, 3] sessions). The median number of

260 participants per in-person session was 7 [IQR: 6, 10]. There were 44 virtual sessions offered, and 28

261 adolescents (93\%) participated in at least one of these sessions (median number of sessions attended by

262 those who participated=34.5, [IQR:16.5- 39.8]. The median number of participants per virtual session was

26320 [IQR:18-21] and the median number of engagements during online sessions was 46 [IQR: 38, 59].

264

265 Preliminary evidence of effectiveness

266 Changes in adherence scores, psychosocial scale scores, and transition readiness are shown in Table 2,

267 Figure 3, Figure 4, Figure 5, and Appendices I-III. In transition readiness, we observed within-person

268 improvements related to personal health $(+1.9$ points, $p<0.001)$, healthcare usage $(+2.4$ points, $p<0.001)$,

269 knowledge $(+3.3$ points, $\mathrm{p}=0.001)$, and behavior ( +3 points, $\mathrm{p}=0.003)$ at the end of the intervention, relative

270 to baseline (Table 2). Results for adherence psychosocial constructs followed a pattern of modest

271 improvements in each scale between baseline and six-months, which increased further by nine-months and

272 were generally sustained at twelve months (Table 2). Although sample sizes were small for subgroup

273 analyses, we observed evidence of improvements in transition readiness across all subgroups as well as

274 improvements in adherence among adolescents living with HIV since early childhood, improvements in

275 psychosocial indicators among adolescents with newly acquired HIV, and improvements in both metrics

276 among adolescents with a history of non-adherence (Appendices I-III). 
Table 2. Within-person changes in key outcomes among PASEO intervention participants $(\mathbf{N}=30)$

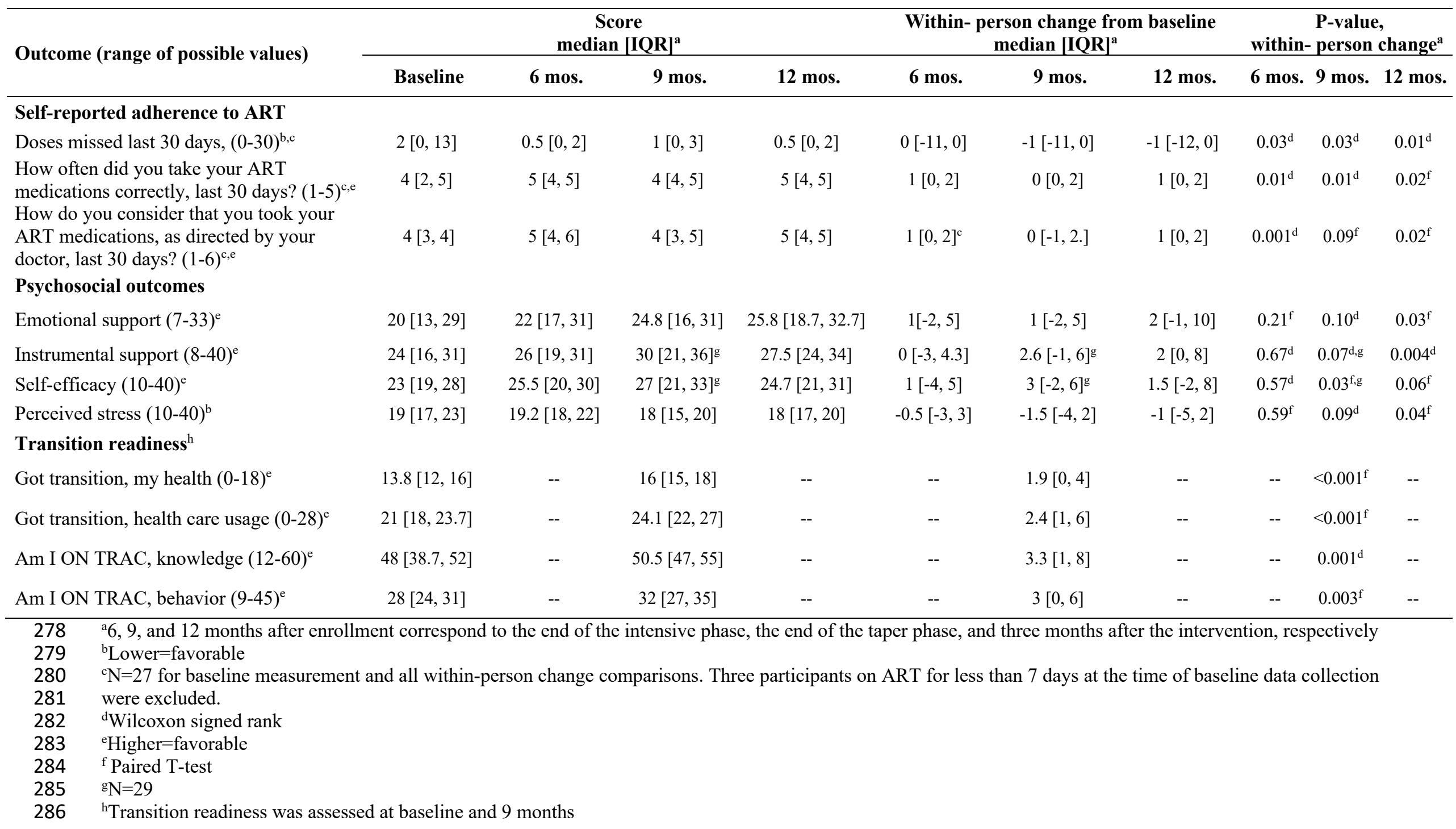




\section{Self-reported doses missed}

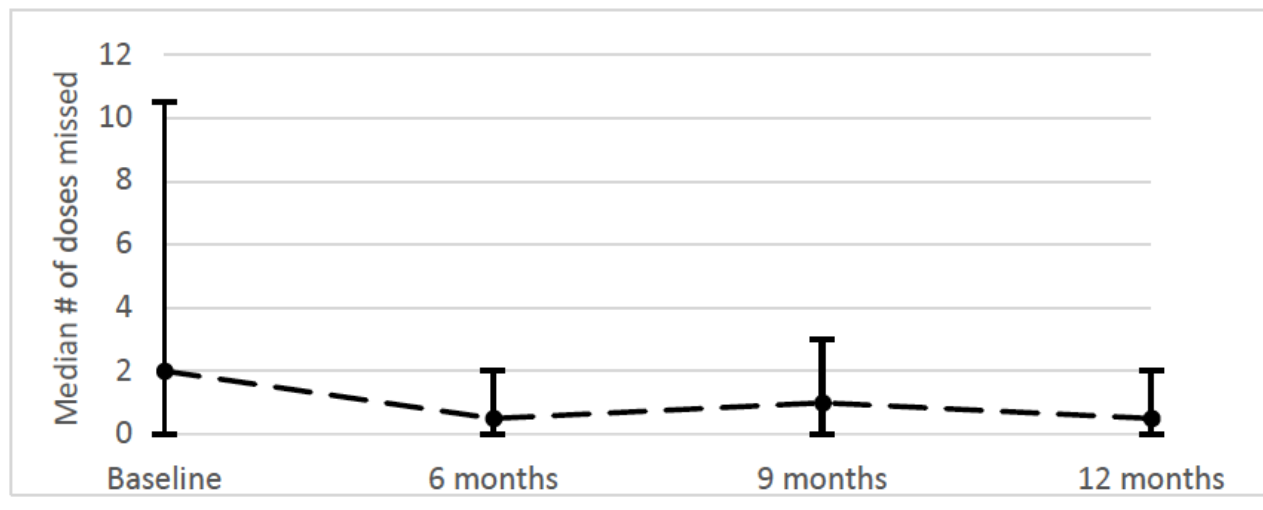

How well did you take your medications, as directed by your doctor?

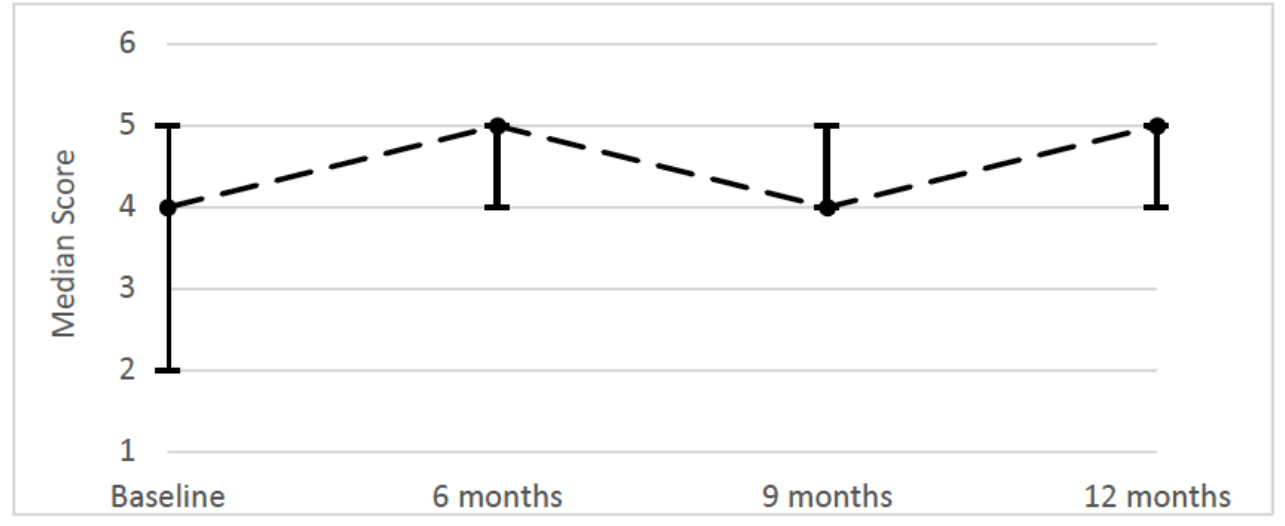

How often did you take your HIV medications correctly?

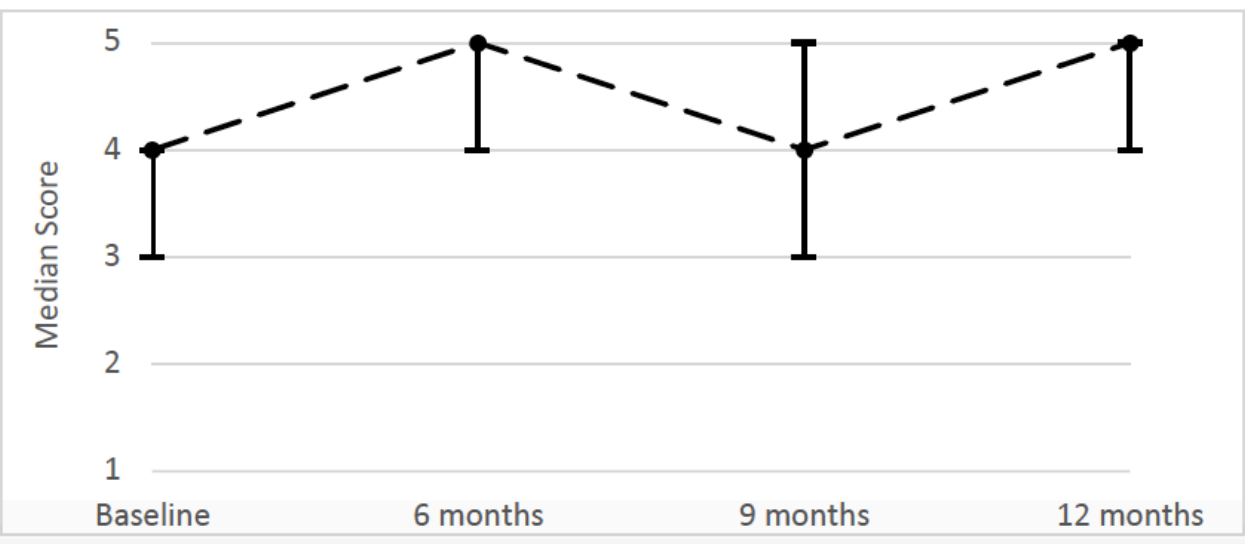

Figure 3. Treatment adherence in the last 30 days among adolescents living with HIV in Lima, Peru.

289 Circles indicate the mean; error bars indicate the interquartile range 
medRxiv preprint doi: https://doi.org/10.1101/2021.08.25.21261815; this version posted August 26, 2021. The copyright holder for this preprint (which was not certified by peer review) is the author/funder, who has granted medRxiv a license to display the preprint in perpetuity.

All rights reserved. No reuse allowed without permission.

290

\section{Emotional Support}

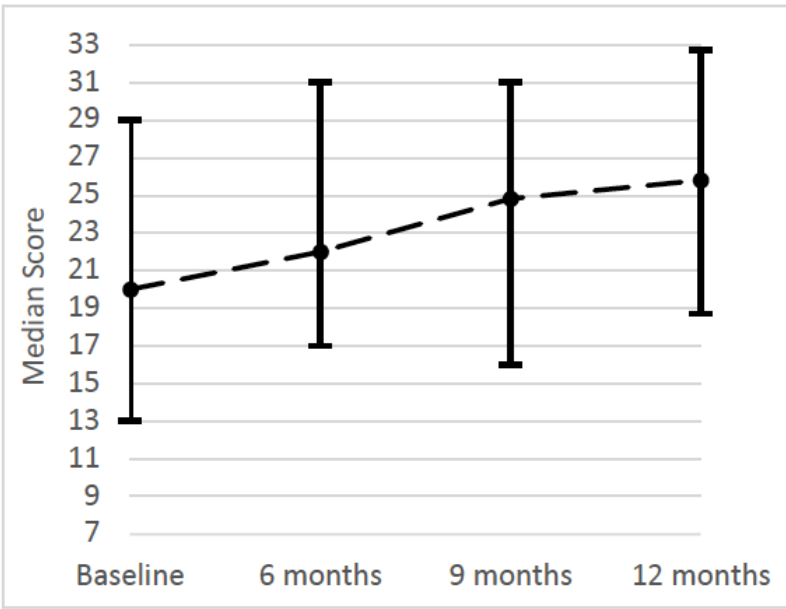

\section{Self-Efficacy}

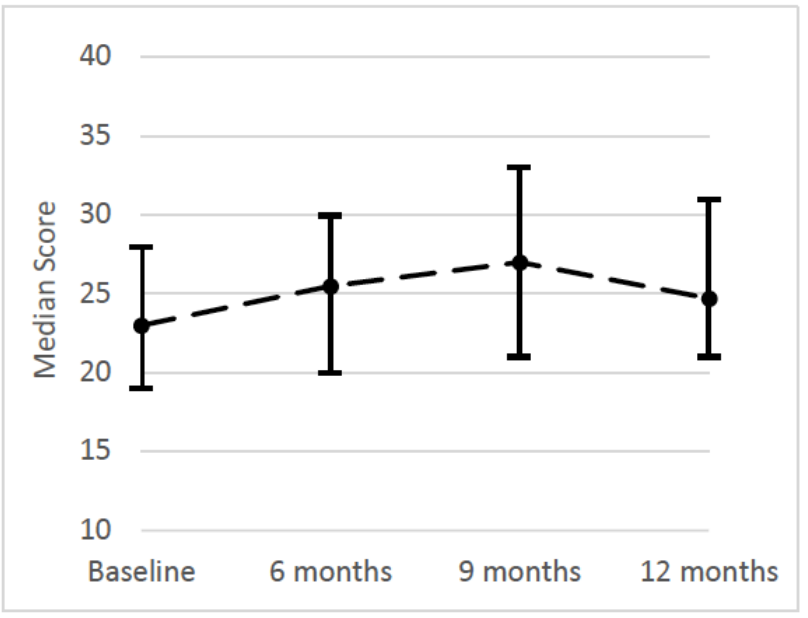

Instrumental Support

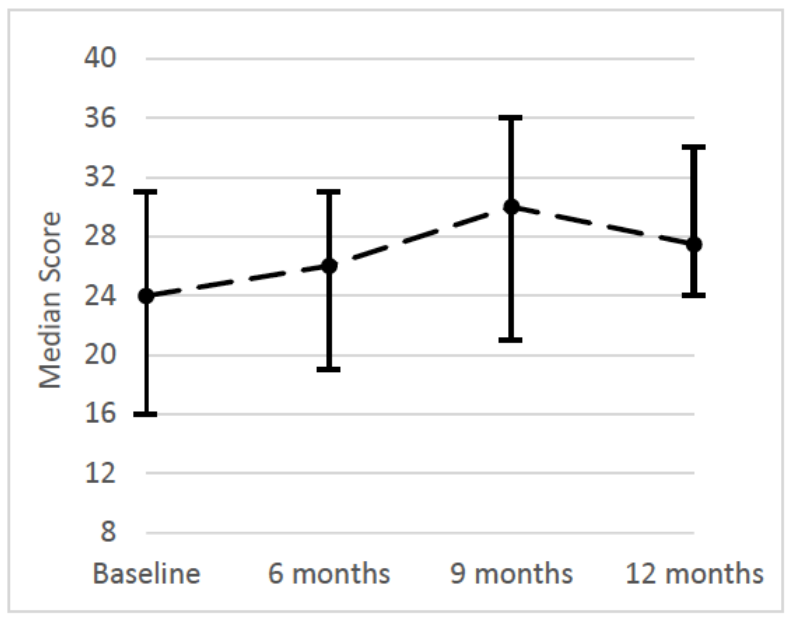

Perceived Stress

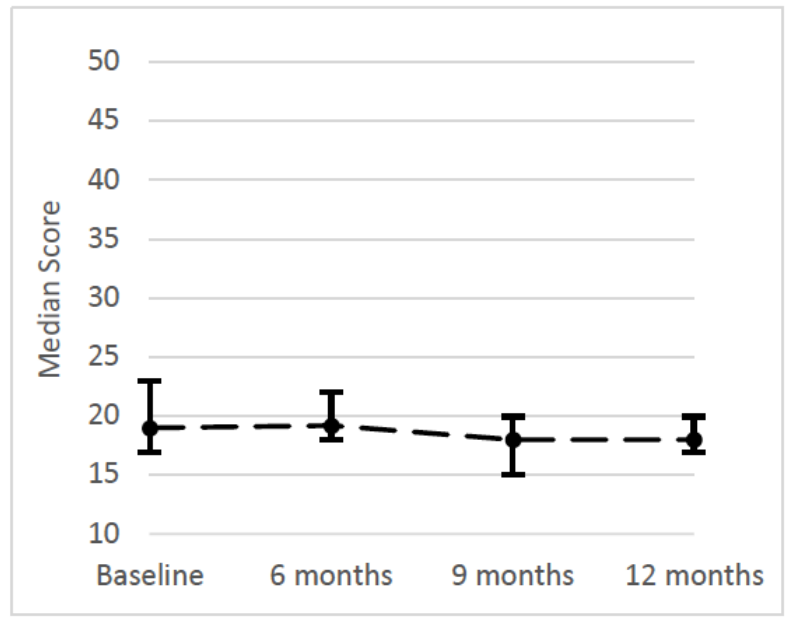

Figure 4. Psychosocial outcome scores among adolescents living with HIV in Lima, Peru. Circles indicate the mean; error bars indicate the interquartile range 
medRxiv preprint doi: https://doi.org/10.1101/2021.08.25.21261815; this version posted August 26, 2021. The copyright holder for this preprint (which was not certified by peer review) is the author/funder, who has granted medRxiv a license to display the preprint in perpetuity.

All rights reserved. No reuse allowed without permission.

Got Transition (my health)

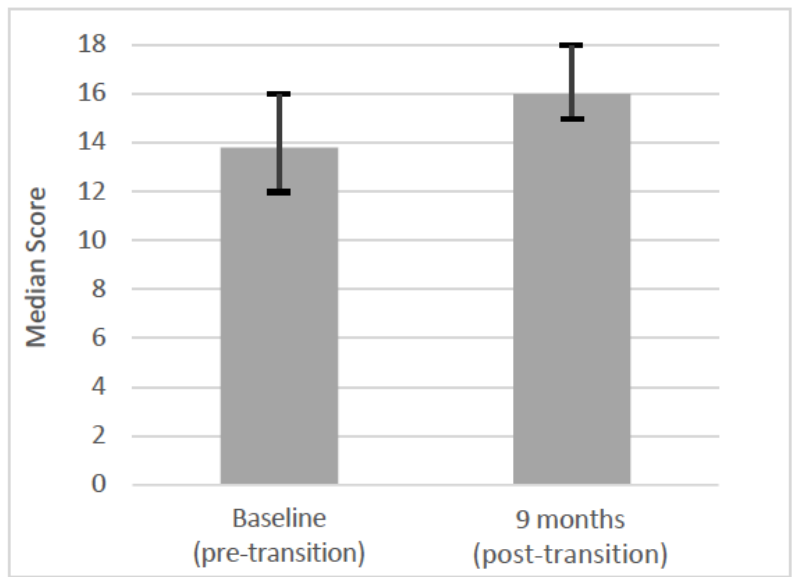

Am I ON TRAC (knowledge)

300

301 bars indicate the interquartile range

\section{Got Transition (healthcare usage)}

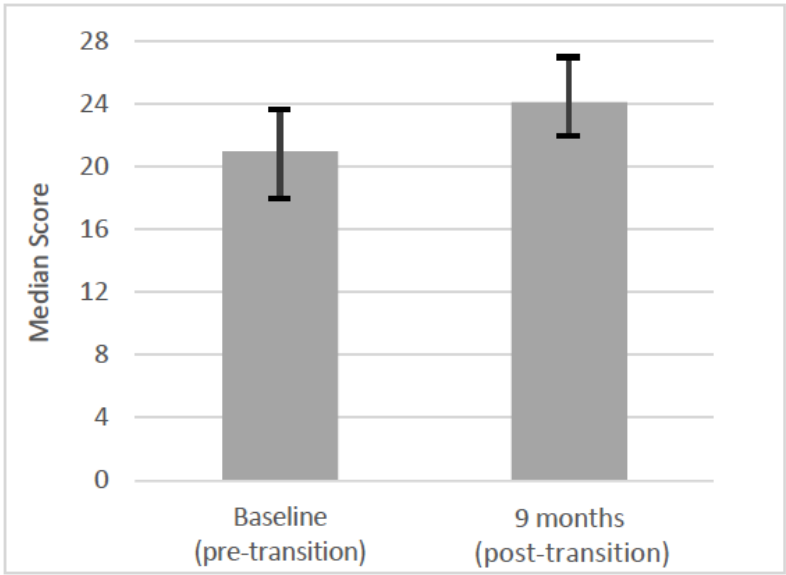

Am I ON TRAC (behavior)
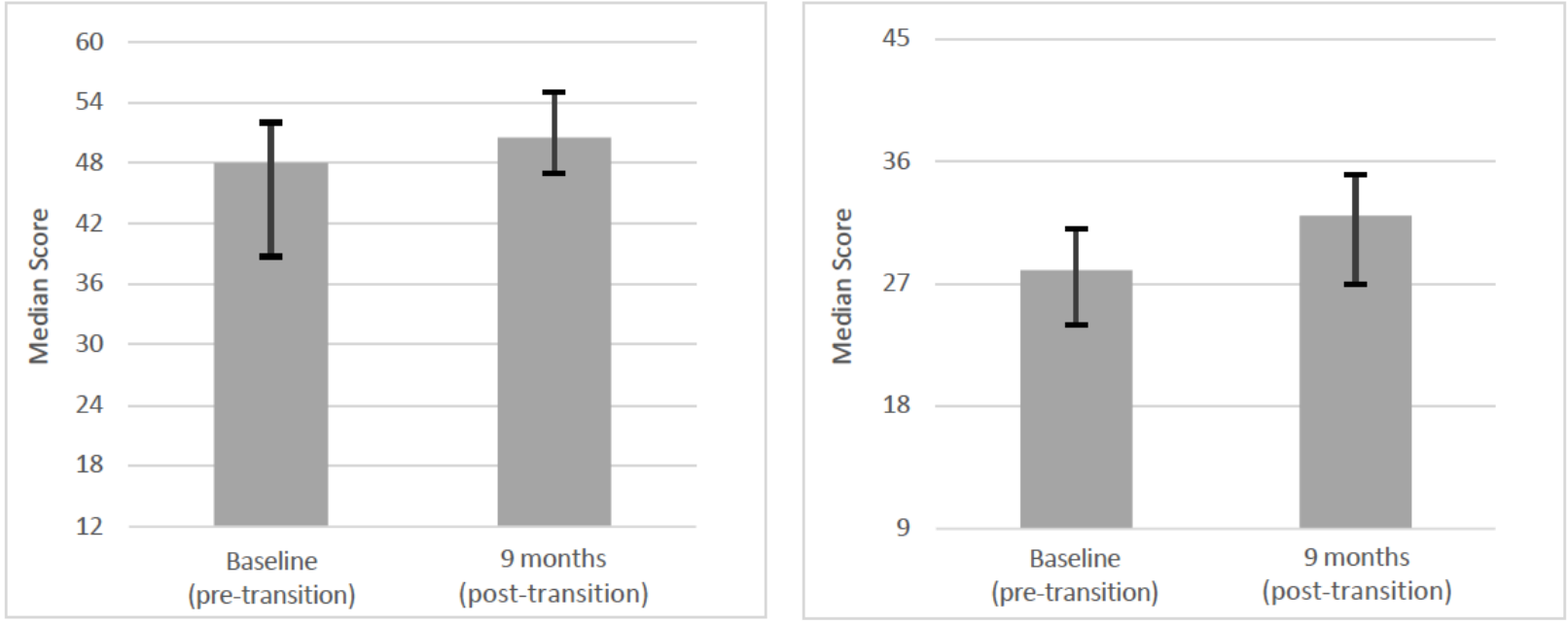

Figure 5. Changes in transition readiness among adolescents living with HIV in Lima, Peru. The error 


\section{Discussion}

304 We provide quantitative evidence supporting the feasibility and effectiveness of a community-based intervention designed to improve health outcomes for ALWH in Lima, Peru. The adolescents in this cohort social and health needs) and individualized design (i.e., it sought to respond to each adolescent's needs, care, provided linkages, liaised with providers, and literally accompanied adolescents as they transitioned to adult care.

We found the PASEO intervention to be highly feasible based on metrics of acceptability and demand.

317 There was a low refusal rate for enrollment, no participants were lost to follow up, and adolescents demonstrated high-attendance and engagement in group sessions. The potential effectiveness of PASEO is supported by within-person improvements in adherence, psychosocial indicators, and transition readiness; this improvement was often sustained three months after the intervention's intensive phase. Importantly, these improvements appear to hold up across subgroups of adolescents characterized by timing of diagnosis

322 (early childhood infection versus recent diagnosis) and among those with a history of non-adherence. This 323 suggests that the lay health workers were effective at individualizing support to adequately meet the needs 324 of each adolescent. Importantly, these data also corroborate that PASEO aligns with World Health 325 Organization criteria for adolescent-friendly care in that it was acceptable (adolescents were willing to 
medRxiv preprint doi: https://doi.org/10.1101/2021.08.25.21261815; this version posted August 26, 2021. The copyright holder for this preprint (which was not certified by peer review) is the author/funder, who has granted medRxiv a license to display the preprint in perpetuity.

All rights reserved. No reuse allowed without permission.

327

328

329

330

331

332

333

334

335

336

337

338

339

340

341

342

343

344

345

346

347

348

349

350

351

352

effective (resulting in a positive contribution to health) [48]. To further increase equity, adaptations may be needed to ensure it is acceptable and effective for transgender women, as we only enrolled one in this study.

A number of intervention studies addressing the transition period are underway in low-or-middle-income and high-burden settings $[49,50]$. While these studies will contribute importantly to knowledge on evidence-based practices, there is a notable lack of intervention studies addressing the transition to adult care in South America. This disparity reflects a broader knowledge gap related to effective interventions for ALWH in the Latin American and Caribbean contexts more generally. One recent systematic review of interventions for ALWH found only six studies that discussed linkage to care, none of which were from Latin America [51]; another, focused on psycho-social support interventions, identified six studies, but found none outside the U.S. or Africa. An intervention that was effective in improving continuity of care and psychosocial health outcomes among ALWH in South America would therefore contribute to filling an important research and implementation gap. And, the fact that the six adolescents who had been lost from care at enrollment remained engaged in ART at the end of the study, suggests that the PASEO intervention also may be an effective strategy for re-engaging ALWH who are lost from care.

This pilot study was underway when the SARS-CoV-2 pandemic emerged, during which stay-at-home orders were intermittently instated. These circumstances required us to adapt the intervention to a virtual format; however, improvements in key metrics suggests that the pillars of the intervention (accompaniment, social support, skills-building) were preserved under this hybrid model. The lack of a control group precludes definitively concluding that the intervention caused these improvements; however, baseline measurements preceded SARS-CoV-2, while follow-up measurements occurred in the first six months of the pandemic; therefore, the expected underlying time trend in these outcomes would be downward and would likely have attenuated any PASEO-related improvements [31]. While unplanned, the intervention adaptations could be considered a strength: the flexibility and high participation rates despite the pandemic suggest that the feasibility metrics are even more notable. And, successful adaptations open the possibility 
medRxiv preprint doi: https://doi.org/10.1101/2021.08.25.21261815; this version posted August 26, 2021. The copyright holder for this preprint (which was not certified by peer review) is the author/funder, who has granted medRxiv a license to display the preprint in perpetuity.

All rights reserved. No reuse allowed without permission.

353 for flexible delivery across a variety of in-person parameters. The pandemic also resulted in temporary

354 suspension of CD4 cell count and viral load testing, which prevented us assessing biologic endpoints.

355

\section{Conclusions}

357 In conclusion, the PASEO intervention was feasible and demonstrated promise for improving myriad self-

358 reported health outcomes in a diverse cohort of ALWH. Future studies should include a large-scale impact

359 evaluation including biological outcomes and assessment of long-term effectiveness beyond the life of the

360 intervention. 


\section{Competing interests}

362 The authors declare no competing interests.

363

\section{Authors' contributions}

365 Conceived of the study: MF

366 Developed the study intervention: MW, SS, HS, LL, MF, JG

367 Designed the study: MF, MW, JG, SS

368 Oversaw enrollment and recruitment: MW, LK, EM, ES

369 Implemented the intervention: MW, HS, LS, AR, RE, KR

370 Data collection and management: LS, AR, RE, MW, CR, AL, VV, CB

371 Analyzed data: VV, CR, AL

372 Interpreted data: all authors

373 Wrote first draft of the manuscript: VV, MF

374 Critically reviewed and approve the final version of the manuscript: all authors

375

\section{Acknowledgements}

377 We acknowledge and thank the adolescents who participated in the study; personnel at Hospital Nacional

378 Hipólito Unanue, Hospital Nacional Arzobispo Loayza, and the Instituto Nacional de Salud del Niño and

379 the Peru National HIV Program. We are indebted to the Socios En Salud Youth Advisory Board for their 380 feedback and contributions.

381 Funding: This research was entirely supported by the National Institute of Allergy and Infectious Diseases 382 of the National Institutes of Health under award number R21AI143365. 
medRxiv preprint doi: https://doi.org/10.1101/2021.08.25.21261815; this version posted August 26, 2021. The copyright holder for this preprint (which was not certified by peer review) is the author/funder, who has granted medRxiv a license to display the preprint in perpetuity.

All rights reserved. No reuse allowed without permission.

384 Disclaimer: The content is solely the responsibility of the authors and does not necessarily represent the 385 official views of the National Institutes of Health.

386 Additional files

387 Additional file 1: Appendix

388 Information on file format. Analyses of effectiveness outcomes, stratified by early childhood versus recent 389 diagnosis and whether the adolescent had been lost from care or had a history of chronic non-adherence.

392 List of abbreviations

393 ALWH: adolescents living with HIV, ART: antiretroviral therapy, CBA: community-based 394 accompaniment, CHWs: community health workers, DOT: directly observed treatment, HIV: human 395 immunodeficiency virus, MSM: men who have sex with men, PLWH: people living with HIV, SES: Socios 396 En Salud, SMS: short message service, TGW: transgender women, YAB: youth advisory board 
medRxiv preprint doi: https://doi.org/10.1101/2021.08.25.21261815; this version posted August 26, 2021. The copyright holder for this preprint (which was not certified by peer review) is the author/funder, who has granted medRxiv a license to display the preprint in perpetuity.

All rights reserved. No reuse allowed without permission.

\section{References}

1. Folayan M, Odetoyinbo M, Brown B, Harrison A. Addressing the socio-development needs of adolescents living with HIV/AIDS in Nigeria: a call for action. Afr J Reprod Health. 2014 Sep;18(3):93-101.

2. Fielden SJ, Sheckter L, Chapman GE, Alimenti A, Forbes JC, Sheps S, et al. Growing up: Perspectives of children, families and service providers regarding the needs of older children with perinatally-acquired HIV. AIDS Care - Psychol Socio-Medical Asp AIDS/HIV. 2006 Nov;18(8):1050-3.

3. Souza E, Santos N, Valentini S, Silva G, Falbo A. Long-term follow-up outcomes of perinatally HIV-infected adolescents: Infection control but school failure. J Trop Pediatr. 2010 Dec;56(6):421-6.

4. Koenig LJ, Nesheim S, Abramowitz S. Adolescents with perinatally acquired HIV: Emerging behavioral and health needs for long-term survivors. Curr Opin Obstet Gynecol. 2011 Oct;23(5):321-7.

5. Steinberg L. Commentary: A Behavioral Scientist Looks at the Science of Adolescent Brain Development. Brain Cogn. 2010;72(1):160.

6. Blakemore SJ. Adolescence and mental health. Lancet. 2019 May;393(10185):2030-1.

7. Too EK, Abubakar A, Nasambu C, Koot HM, Cuijpers P, Newton CR, et al. Prevalence and factors associated with common mental disorders in young people living with HIV in sub-Saharan Africa: a systematic review. J Int AIDS Soc. 2021 Jun;24(S2):e25705.

8. Tepper V, Zaner S, Ryscavage P. HIV healthcare transition outcomes among youth in North America and Europe: A review. Vol. 20, Journal of the International AIDS Society. 2017. p. 
medRxiv preprint doi: https://doi.org/10.1101/2021.08.25.21261815; this version posted August 26, 2021. The copyright holder for this preprint (which was not certified by peer review) is the author/funder, who has granted medRxiv a license to display the preprint in perpetuity.

All rights reserved. No reuse allowed without permission.

21490.

9. Nichols SL, Bethel J, Garvie PA, Patton DE, Thornton S, Kapogiannis BG, et al. Neurocognitive functioning in antiretroviral therapy-naïve youth with behaviorally acquired human immunodeficiency virus. J Adolesc Heal. 2013 Dec;53(6):763-71.

10. World Health Organization. A qualitative review of psychosocial support interventions for young people living with HIV. Geneva; 2009.

11. Pearlstein SL, Mellins CA, Dolezal C, Elkington KS, Santamaria EK, Leu CS, et al. Youth in transition: Life skills among perinatally HIV-infected and HIV-exposed adolescents. J Pediatr Psychol. 2014;39(3):294-305.

12. Kidia K, Machando D, Bere T, Macpherson K, Nyamayaro P, Potter L, et al. "I was thinking too much”: experiences of HIV-positive adults with common mental disorders and poor adherence to antiretroviral therapy in Zimbabwe. Trop Med Int Health. 2015 Jul;20(7):903-13.

13. Casale M, Carlqvist A, Cluver L. Recent Interventions to Improve Retention in HIV Care and Adherence to Antiretroviral Treatment among Adolescents and Youth: A Systematic Review. AIDS Patient Care STDS. 2019 Jun;33(6):237-52.

14. Murray KR, Dulli LS, Ridgeway K, Dal Santo L, De Mora DD, Olsen P, et al. Improving retention in HIV care among adolescents and adults in low- and middle-income countries: A systematic review of the literature. Sued O, editor. PLoS One. 2017 Sep;12(9):e0184879.

15. Auld AF, Agolory SG, Shiraishi RW, Wabwire-Mangen F, Kwesigabo G, Mulenga M, et al. Antiretroviral therapy enrollment characteristics and outcomes among HIV-infected adolescents and young adults compared with older adults--seven African countries, 2004-2013. MMWR Morb Mortal Wkly Rep. 2014 Nov;63(47):1097-103. 
medRxiv preprint doi: https://doi.org/10.1101/2021.08.25.21261815; this version posted August 26, 2021. The copyright holder for this preprint (which was not certified by peer review) is the author/funder, who has granted medRxiv a license to display the preprint in perpetuity.

All rights reserved. No reuse allowed without permission.

16. Kakkar F, Van der Linden D, Valois S, Maurice F, Onnorouille M, Lapointe N, et al. Health outcomes and the transition experience of HIV-infected adolescents after transfer to adult care in Québec, Canada. BMC Pediatr. 2016 Dec;16(1):109.

17. Weijsenfeld AM, Smit C, Cohen S, Wit FWNM, Mutschelknauss M, Van Der Knaap LC, et al. Virological and Social Outcomes of HIV-Infected Adolescents and Young Adults in the Netherlands before and after Transition to Adult Care. Clin Infect Dis. 2016 Oct;63(8):1105-12.

18. Hussen SA, Chakraborty R, Knezevic A, Camacho-Gonzalez A, Huang E, Stephenson R, et al. Transitioning young adults from paediatric to adult care and the HIV care continuum in Atlanta, Georgia, USA: A retrospective cohort study: A. J Int AIDS Soc. 2017;20(1):21848.

19. Straub DM, Tanner AE. Health-care transition from adolescent to adult services for young people with HIV. Lancet Child Adolesc Heal. 2018;2(3):214-22.

20. Machado DM, Succi RC, Turato ER. Transitioning adolescents living with HIV/AIDS to adultoriented health care: An emerging challenge. J Pediatr (Rio J). 2010 Dec;86(6):465-72.

21. Cervia JS. Easing the Transition of HIV-Infected Adolescents to Adult Care. AIDS Patient Care STDS. 2013 Dec;27(12):692-6.

22. Judd A, Sohn AH, Collins IJ. Interventions to improve treatment, retention and survival outcomes for adolescents with perinatal HIV-1 transitioning to adult care: moving on up. Curr Opin HIV AIDS. 2016;11(5):477-86.

23. Hawkins A, Evangeli M, Sturgeon K, Le Prevost M, Judd A. Episodic medication adherence in adolescents and young adults with perinatally acquired HIV: a within-participants approach. AIDS Care. 2016;28(sup1):68-75.

24. Bailey H, Cruz MLS, Songtaweesin WN, Puthanakit T. Adolescents with HIV and transition to 
medRxiv preprint doi: https://doi.org/10.1101/2021.08.25.21261815; this version posted August 26, 2021. The copyright holder for this preprint (which was not certified by peer review) is the author/funder, who has granted medRxiv a license to display the preprint in perpetuity.

All rights reserved. No reuse allowed without permission.

adult care in the Caribbean, Central America and South America, Eastern Europe and Asia and Pacific regions. J Int AIDS Soc. 2017 Apr;20(0):21475.

25. Lam PK, Fidler S, Foster C. A review of transition experiences in perinatally and behaviourally acquired HIV-1 infection; same, same but different? J Int AIDS Soc. 2017 Apr;20(Suppl 3):21506.

26. UNAIDS. Peru Country Fact Sheet [Internet]. 2019 [cited 2020 Dec 17]. Available from: https://www.unaids.org/en/regionscountries/countries/peru

27. Ministerio de Salud Direccion General de Salud de las Personas. Peru: Informe nacional sobre los progresos realizados en la aplicacion del UNGASS. 2010.

28. Chow JY, Konda KA, Borquez A, Caballero P, Silva-Santisteban A, Klausner JD, et al. Peru's HIV care continuum among men who have sex with men and transgender women: opportunities to optimize treatment and prevention. Int J STD AIDS. 2016 Oct;27(12):1039-48.

29. UNICEF. Atlas of adolescents and HIV in Latin America and the Caribbean. New York; 2015.

30. Mukherjee JS, Barry D, Weatherford RD, Desai IK, Farmer PE. Community-Based ART Programs: Sustaining Adherence and Follow-up. Curr HIV/AIDS Rep. 2016;13(6):359-66.

31. Errea RA, Wong M, Senador L, Ramos A, Ramos K, Galea JT, et al. Impact of SARS-COV-2 pandemic on adolescents living with HIV in Lima, Peru. Rev Peru Med Exp Salud Publica. $2021 ; 38(1): 153-8$.

32. Arrieta J, Aguerrebere M, Raviola G, Flores H, Elliott P, Espinosa A, et al. Validity and Utility of the Patient Health Questionnaire (PHQ)-2 and PHQ-9 for Screening and Diagnosis of Depression in Rural Chiapas, Mexico: A Cross-Sectional Study: PHQ-9 Validity for Depression Diagnosis. J Clin Psychol. 2017;73(9):1076-90.

33. Calderón M, Gálvez-Buccollini JA, Cueva G, Ordoñez C, Bromley C, Fiestas F. Validation of the 
medRxiv preprint doi: https://doi.org/10.1101/2021.08.25.21261815; this version posted August 26, 2021. The copyright holder for this preprint (which was not certified by peer review) is the author/funder, who has granted medRxiv a license to display the preprint in perpetuity.

All rights reserved. No reuse allowed without permission.

Peruvian version of the PHQ-9 for diagnosing depression. Rev Peru Med Exp Salud Publica. 2012;29(4):578-9.

34. World Health Organization. Psychological First Aid: Guide for Field Workers. War Trauma Foundation and World Vision International, editor. Geneva: World Health Organization; 2011.

35. Galea JT, Contreras C, Wong M, Ramos K, Vargas V, Sanchez H, et al. A non-specialist depression care pathway for adolescents living with HIV and transitioning into adult care in Peru: a nested, proof of concept pilot study. Glob Ment Heal. 2021;8:e17-e17.

36. Bowen DJ, Kreuter M, Spring B, Cofta-Woerpel L, Linnan L, Weiner D, et al. How we design feasibility studies. Am J Prev Med. 2009 May;36(5):452-7.

37. Salsman JM, Butt Z, Pilkonis PA, Cyranowski JM, Zill N, Hendrie HC, et al. Emotion assessment using the NIH Toolbox. Neurology. 2013;80(11 Suppl 3):S76-86.

38. Babakhanyan I, McKenna BS, Casaletto KB, Nowinski CJ, Heaton RK. National Institutes of Health Toolbox Emotion Battery for English- and Spanish-speaking adults: normative data and factor-based summary scores. Patient Relat Outcome Meas. 2018;9:115-27.

39. Moynihan M, Saewyc E, Whitehouse S, Paone M, McPherson G. Assessing readiness for transition from paediatric to adult health care: Revision and psychometric evaluation of the Am I ON TRAC for Adult Care questionnaire. J Adv Nurs. Moynihan M. 2015;71(6):1324-35.

40. McManus M, White P, Prior M, McAllister J, Cooley C, Forlenza E, et al. Six Core Elements of Health Care Transition 2.0: Transitioning to an Adult Approach to Health Care Without Changing Providers for use by Family Medicine and Med-Peds Providers. 2014.

41. Gray MJ, Litz BT, Hsu JL, Lombardo TW. Psychometric Properties of the Life Events Checklist. Assessment. 2004;11(4):330-41. 
medRxiv preprint doi: https://doi.org/10.1101/2021.08.25.21261815; this version posted August 26, 2021. The copyright holder for this preprint (which was not certified by peer review) is the author/funder, who has granted medRxiv a license to display the preprint in perpetuity.

All rights reserved. No reuse allowed without permission.

42. Hannan J, Youngblut JM, Brooten D, Bazzani D, Romero NR, Chavez B, et al. Psychometric Properties of Newly Translated Spanish Life Events Inventory and Daily Hassles Scale. J Nurs Meas. 2015;23(2):315-25.

43. Miller DB, Townsend A. Urban Hassles as Chronic Stressors and Adolescent Mental Health: The Urban Hassles Index. Br Treat Cris Interv. 2005;5(1):85-94.

44. Roux E Le, Gottot S, Aupiais C, Girard T, Teixeira M, Alberti C. Professional's perspectives on care management of young people with perinatally acquired HIV during transition: A Qualitative study in adult care setting. Simeoni U, editor. PLoS One. 2017 Jan;12(1):e0169782.

45. Wiener LS, Kohrt BA, Battles HB, Pao M. The HIV experience: Youth identified barriers for transitioning from pediatric to adult care. J Pediatr Psychol. 2011 Mar;36(2):141-54.

46. Dahourou DL, Gautier-Lafaye C, Teasdale CA, Renner L, Yotebieng M, Desmonde S, et al. Transition from paediatric to adult care of adolescents living with HIV in sub-Saharan Africa: Challenges, youth-friendly models, and outcomes. J Int AIDS Soc. 2017 Apr;20(Suppl 3):21528.

47. Ritchwood TD, Malo V, Jones C, Metzger IW, Atujuna M, Marcus R, et al. Healthcare retention and clinical outcomes among adolescents living with HIV after transition from pediatric to adult care: a systematic review. BMC Public Health. 2020;20(1):1195.

48. World Health Organization. Making health services adolescent friendly: Developing national quality standards for adolescent-friendly health services. Geneva; 2012.

49. Sam-Agudu NA, Pharr JR, Bruno T, Cross CL, Cornelius LJ, Okonkwo P, et al. Adolescent Coordinated Transition (ACT) to improve health outcomes among young people living with HIV in Nigeria: study protocol for a randomized controlled trial. Trials. 2017;18(1):595.

50. Njuguna IN, Beima-Sofie K, Mburu CW, Mugo C, Neary J, Itindi J, et al. Adolescent transition to 
medRxiv preprint doi: https://doi.org/10.1101/2021.08.25.21261815; this version posted August 26, 2021. The copyright holder for this preprint (which was not certified by peer review) is the author/funder, who has granted medRxiv a license to display the preprint in perpetuity.

All rights reserved. No reuse allowed without permission.

adult care for HIV-infected adolescents in Kenya (ATTACH): study protocol for a hybrid effectiveness-implementation cluster randomised trial. BMJ Open. 2020;10(12):e039972e039972.

51. Macpherson P, Munthali C, Ferguson J, Armstrong A, Kranzer K, Ferrand RA, et al. Service delivery interventions to improve adolescents' linkage, retention and adherence to antiretroviral therapy and HIV care. Trop Med Int Heal. 2015/04/17. 2015;20(8):1015-32. 